\title{
MOLE: A Multidisciplinary Observatory and Laboratory of Experiments in Central Italy
}

\author{
by Massimo Cocco, Paola Montone, Massimiliano R. Barchi, \\ Georg Dresen, and Mark D. Zoback
}

\section{Introduction}

The structure and mechanics of active Low Angle Normal Faults (LANFs) have for decades been posing questions-in particular, if low angle normal faults accommodate crustal extension, and if they generate large magnitude earthquakes, or if they move aseismically. To shed new light on these challenging questions, MOLE intends to drill (down to $4-5 \mathrm{~km}$ ) an active LANF in the Umbria-Marche sector of the northern Apennines (Fig. 1) and to establish a deep borehole observatory. The target site offers a unique opportunity to reach a LANF at drillable seismogenic depth to unravel the "low angle normal fault mechanical paradox" (Wernicke, 1995; Axen, 2007).

In order to discuss the scientific background and plan the MOLE project, sixty-two scientists from various research fields attended an international workshop in Spoleto, Italy, on 5-8 May 2008. The workshop focused on the following goals that need to be achieved: (I) to collect new observational

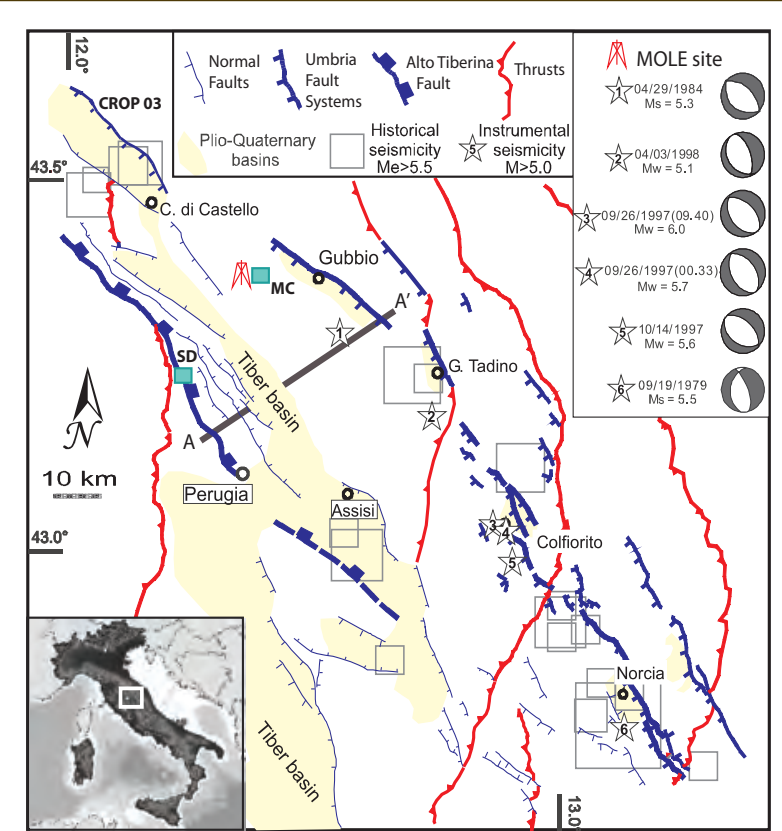

Figure 1. Schematic seismotectonic map of the Umbria-Marche area (modified after Mirabella et al., 2004). Historical earthquakes (gray squares) between $461 \mathrm{BC}$ and $1997 \mathrm{AD}$ (from Boschi et al., 2000). Focal mechanism solutions: (1) Gubbio earthquake (Haessler et al., 1988); (2) Gualdo Tadino earthquake, and (3, 4, 5) Colfiorito sequence (Ekström et al., 1998); (6) Norcia earthquake (Deschamps et al., 2000). SD (San Donato) and MC (Monte Civitello) well sites with A-A' represent the section of Figure 2. data at depth for constraining the fault zone structure; (II) to perform laboratory experiments with gouge and fault zone materials to understand frictional properties and weakening mechanisms; (III) to record microearthquakes at distance comparable to the source radius, and (IV) to obtain stress and strain measurements and geochemical data in and near the fault zone at depth to understand the mechanics of earthquakes and faulting.

\section{Scientific Background - the LANF Paradox}

The question whether or not moderate-to-large magnitude earthquakes can nucleate on LANFs and contribute to accommodate extension of continental crust is widely debated in the literature (Wernicke, 1995 and references therein; Axen, 2007). Indeed, from a theoretical point of view, in an extensional tectonic setting characterized by a vertical principal stress $\sigma_{1}$, no slip is expected on faults dipping less than $30^{\circ}$ with a friction coefficient ranging between 0.6 and 0.85 (Byerlee, 1978). In boreholes at depth in the vicinity of many high-angle, normal faults around the world, direct stress measurements are consistent with both theory and laboratory-derived coefficients of friction (Zoback, 2007). Nevertheless, observed slip on LANFs implies the reactivation of severely misoriented low angle structures (Sibson, 1985) occurring either because of anomalously weak frictional conditions $\left(\mu_{\mathrm{s}}<<0.6\right)$ or because of abrupt rotation of principal stress directions. If the orientation of principal stresses rotates in the direct vicinity of a LANF, it can be determined by stress measurements in a borehole through the fault zone (Zoback, 2007). High fluid pressure may be causing slip on a LANF, which means that the fault zone itself must be overpressured with respect to the rocks in the adjacent hanging wall and footwall.

Seismological observations indicate that no moderate-to-large magnitude earthquakes have been documented on LANFs based on well-constrained focal mechanisms (Collettini and Sibson, 2001; Jackson and White, 1989). On the contrary, geological evidence of active low-angle normal faulting has been documented in numerous field-based structural studies and also interpreted on seismic reflection profiles. Therefore, the role of LANFs and their contribution to seismic risk are still controversial. Despite recent studies which provided observational evidence and physical interpretations (Axen, 1999; Collettini and Holdsworth, 2004; Floyd et al., 2001; Hayman et al., 
2003; Holdsworth, 2004; Sorel, 2000), more experimental data and in situ studies are needed to shed light on these important unanswered issues.

\section{Geology and Seismicity of the Project Area}

The MOLE project aims to integrate several already existing/planned monitoring and research projects designed to create a multidisciplinary test site in the target area of the High Tiber Valley in the northern Apennines of Central Italy (Fig. 1). In this sector of the Apennines, the upper crust is made up of four main lithological units, each about $1.5-2 \mathrm{~km}$ thick. From bottom to top these are a phyllitic basement (not exposed at the surface), Upper Triassic evaporites (alternated anhydrites and dolostones), Jurassic to Oligocene multilayered carbonates, and a cover of Miocene and Pliocene synorogenic deposits (Figs. 2 and 3). The present-day tectonic setting derives from the superposition of two main tectonic phases, compressional structures related to arc-shaped folds and thrusts (Late Miocene) and extensional structures related to NW-SE trending normal faults (Late Pliocene-Quaternary). The easternmost and more recent NW-SE extensional structures have been named as the Umbria Fault System (Fig. 1). These SW-dipping normal faults represent the prominent extensional structures of the region, controlling the onset and evolution of neo-autochthonous continental intra-mountain basins located on the hanging wall of the subsiding areas.

Several moderate-magnitude earthquakes struck the study area in the past (Fig. 1). This seismicity is clearly associated with Quaternary faults. The most recent earthquakes are the 1979 Norcia $\mathrm{M}_{\mathrm{s}}=5.5$, the 1984 Gubbio $\mathrm{M}_{\mathrm{s}}=5.3$, the 1988 Gualdo Tadino $\mathrm{M}_{\mathrm{w}}=5.1$ events, and the 1997-98 Colfiorito earthquake sequence $5.2<\mathrm{M}_{\mathrm{w}}<6.0$ (Amato and Cocco, 2000). However, all these earthquakes ruptured SW-dipping normal faults antithetic to the Alto Tiberina Fault (Fig. 2).

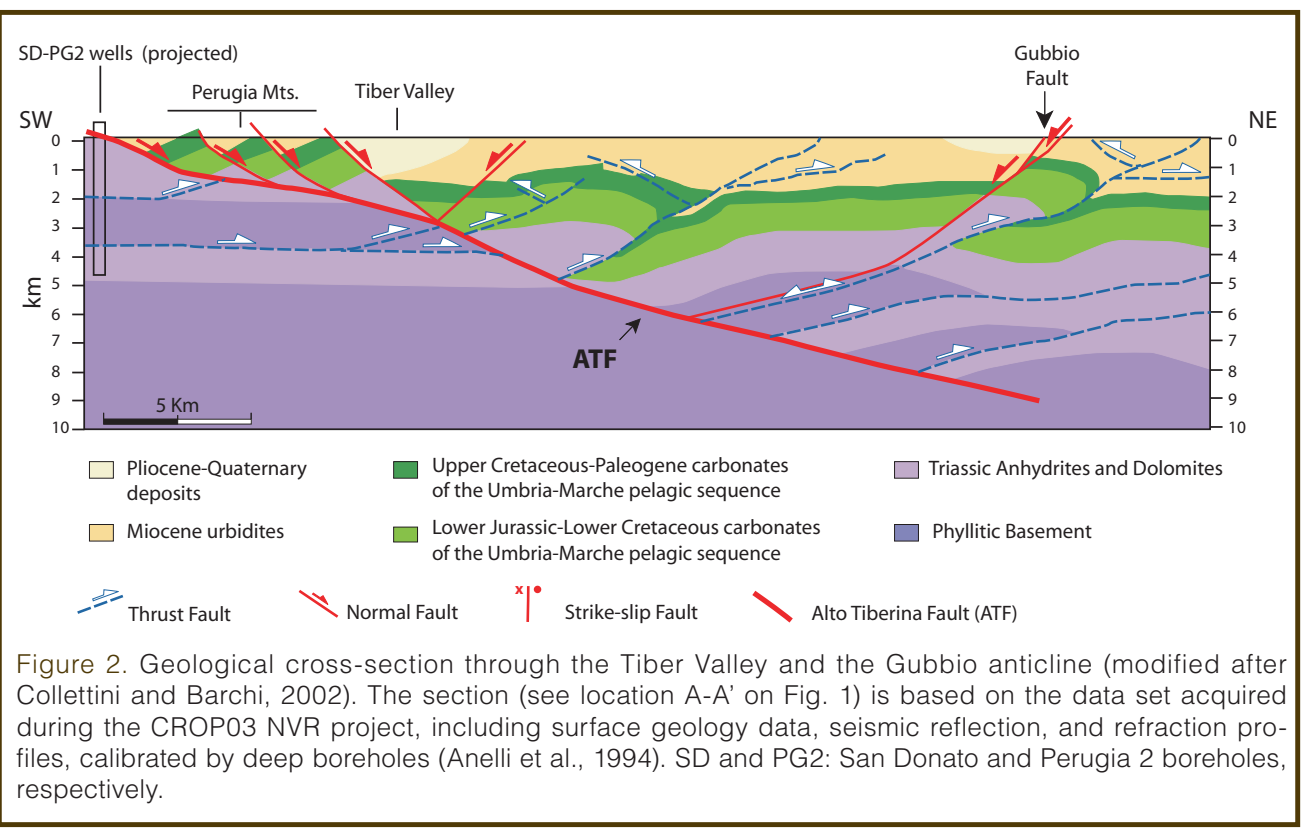

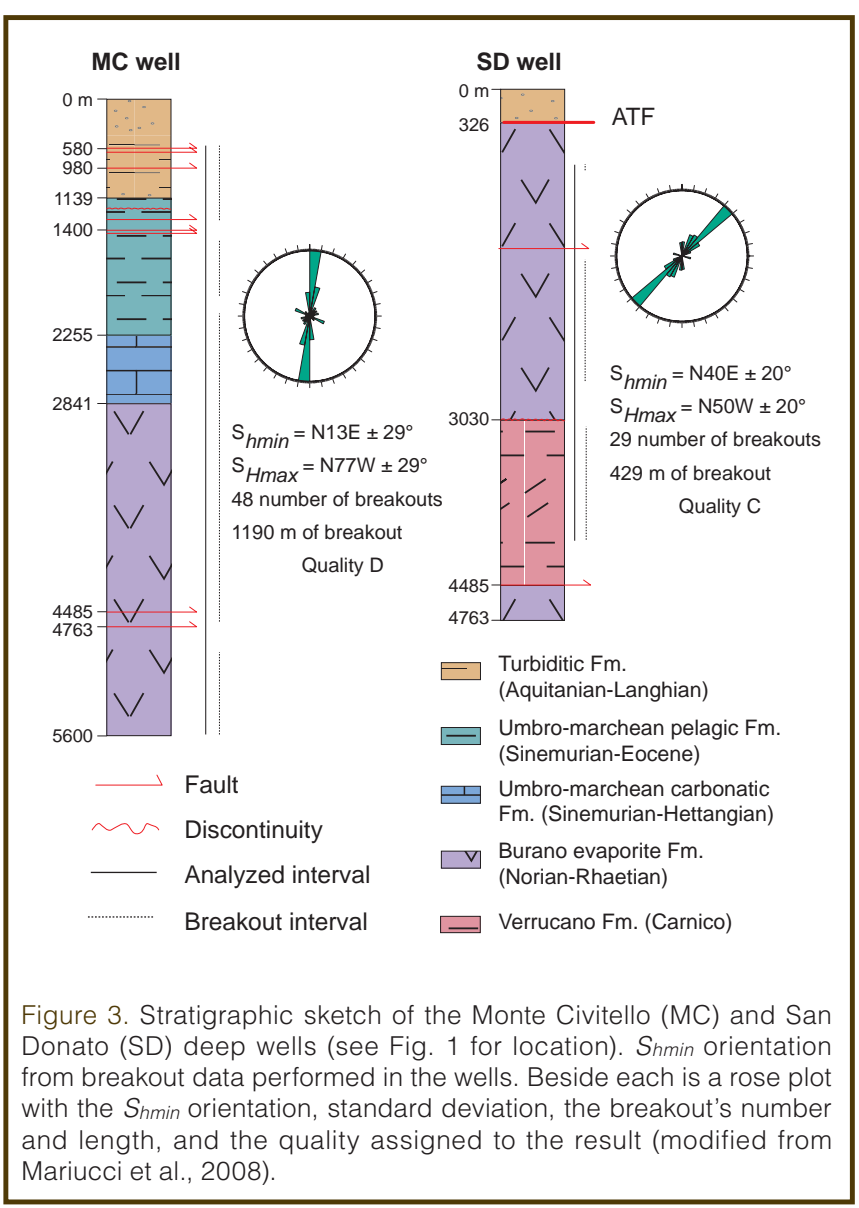

The Alto Tiberina Fault (ATF) is a NE-dipping LANF cutting the upper crust in Central Italy, a region characterized by active extension and moderate-magnitude seismicity (Fig. 1). The subsurface geometry of the ATF (Fig. 2) has been depicted along a deep seismic, nearly vertical reflection transect (CROP03; Pialli et al., 1998), further constrained by a set of seismic reflection profiles (Mirabella et al., 2004) and calibrated by deep boreholes (e.g., San Donato and Perugia 2 wells). All these data define in detail a portion of the ATF (N150 ${ }^{\circ}$ trending) which is at least $55-60 \mathrm{~km}$ long. In cross-section, the ATF is characterized by a staircase trajectory with a mean dip of $15^{\circ}-20^{\circ}$ recognizable in the seismic profiles down to a depth of about $12 \mathrm{~km}$ (Fig. 2). Seismo-tectonic data and preliminary geodetic investigations (D’Agostino et al., 2008) demonstrate that the ATF is presently active and accommodates crustal extension. Moreover, the absence of historical earthquakes doubtlessly associated with the ATF and the presence of a source of over-pressurized fluids located 
in the fault hanging wall (Chiodini et al., 2004) suggest that the fault most likely moves through a combination of seismic/aseismic slip and creep with repeating microearthquakes (Collettini, 2002). The ATF detaches an active hanging wall block from an aseismic footwall. In the hanging wall block, seismic reflection profiles and seismological data reveal the presence of moderately-to steeply-inclined minor faults soling into the detachment. While there is no instrumental evidence of moderate-magnitude earthquakes located on the ATF, it is important to note that microseismicity has been associated with the ATF (Boncio et al., 1998; Chiaraluce et al., 2007), thus confirming that it is an active LANF. A temporary dense local seismic network deployed in the study area for eight months allowed the recording of nearly $2000 \quad(\mathrm{M}<3.2) \quad$ earthquakes
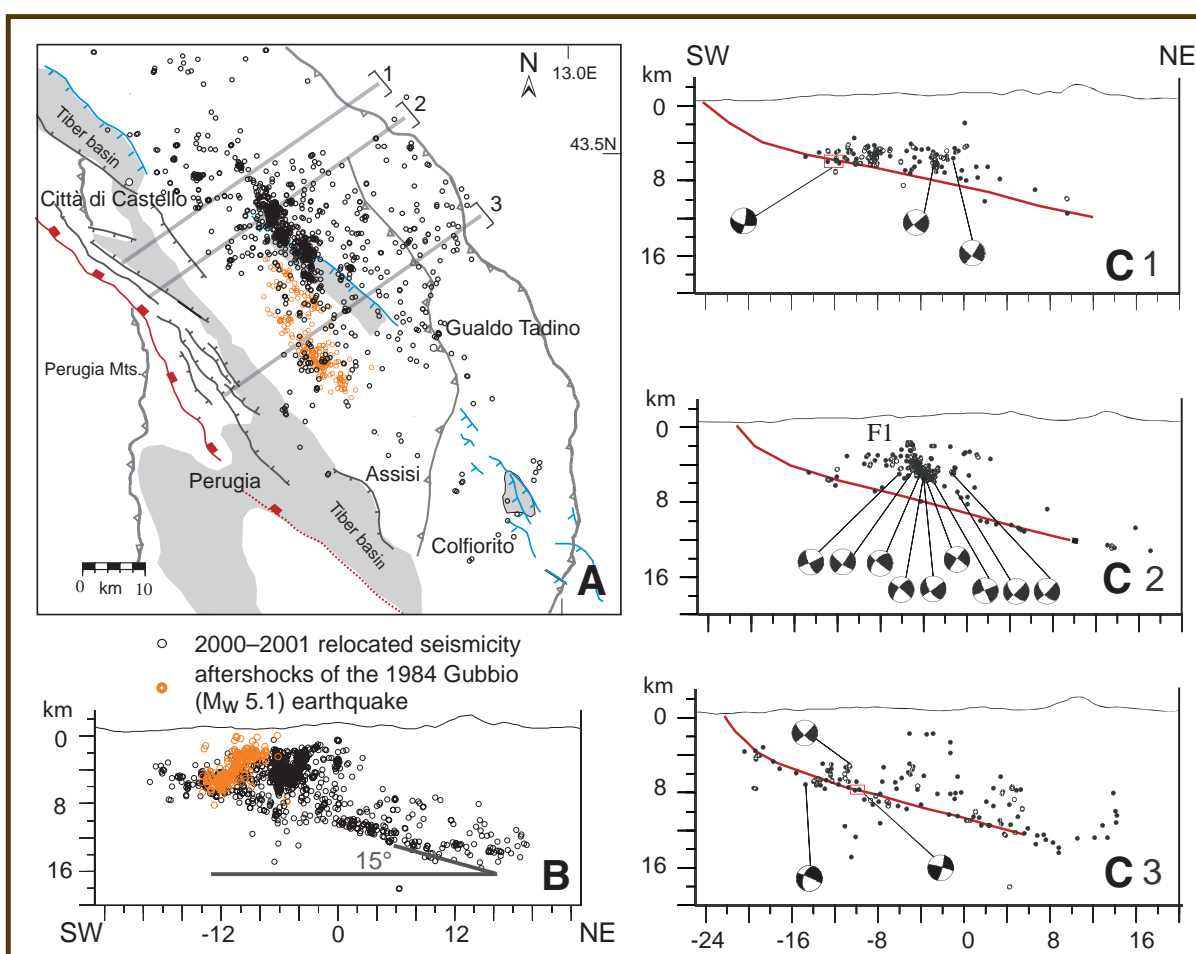

Figure 4. [A] Map of the area and location of seismic sections. [B] Vertical cross-section perpendicular to the Apenninic belt showing the relocated composite seismicity and (in orange) the 1984 Gubbio sequence. [C] Three vertical cross-sections showing the seismicity distribution and the available fault plane solutions computed for seismic data acquired from 2000 to 2001. Their positions are shown in [A] together with the width used to plot hypocenters. The heavy red lines plotted in each cross-section represent the trace of the ATF fault as imaged on the depth-converted seismic reflection profiles (modified from Chiaraluce et al., 2007).

\section{(Piccinini et al., 2003). The}

integration of geological observations and seismicity data, together with the interpretation of seismic reflection profiles, led to a clear identification of a $60-\mathrm{km}$-long portion of the Edipping low angle normal ATF (Fig. 4). The analysis of this multidisciplinary data set shows that in the last $2 \mathrm{Ma}$ this structure has accumulated $2 \mathrm{~km}$ of displacement.

The computed focal mechanisms of microearthquakes (Chiaraluce et al., 2007) are in agreement with the geometry of the faults (Fig. 4). The latter are nicely highlighted by the earthquake distributions that appear in seismic reflection profiles in accord with a stress field characterized by a nearly vertical $\sigma_{1}$ and a NE-trending $\sigma_{3}$, perpendicular to the strike of the ATF, which has also been inferred from regional stress data (Mariucci et al., 2008; Montone et al., 2004). This microseismicity is uniformly distributed over the ATF plane, and the earthquake distribution in the down-dip direction reveals a fault zone thickness ranging from $500 \mathrm{~m}$ to $1000 \mathrm{~m}$. Repeating earthquakes occur in very small slip patches whose dimensions are of the order of 10-100 m (Chiaraluce et al., 2007).

Collettini and Holdsworth (2004) brought up the hypothesis that the ATF at depth consists of a phyllosilicaterich fault core. This relies on analogy with the Zuccale Fault, an older, presently inactive, ATF-like structure cropping out west of the Alto Tiberina fault on the island of Elba. This hypothesis is consistent with the proposed aseismic behavior of a misoriented fault in which microseismicity might be generated by local, short-lived build-ups in fluid pressure during regional scale degassing of the deep crust and the mantle, associated with regional tectonic extension (Chiodini et al., 2004). However, their theory must be corroborated by in situ observations and experimental evidence.

\section{Workshop Program and Results}

During the MOLE workshop participants from eight countries discussed drilling deep $(4-5 \mathrm{~km})$ into the Alto Tiberina Fault. During the first day other deep fault drilling projects were presented, followed by a session on the seismotectonics, geology, seismology, geodesy, and geochemistry of the target area during the second day. Another session focused on laboratory experiments on rock friction and rock mechanics using fault zone materials. The third day was dedicated to outlining preliminary studies, investigations during the drilling phase, and research after drilling. The potential drill site (Fig. 5) and some major normal faults of the region were visited during a half-day field trip. During the last afternoon, the key scientific and technical issues associated with the deployment of the deep borehole and the long-term multidisciplinary observatory at depth were summarized, and a scientific rationale for the MOLE deep drilling project was drafted. An unusually large set of geological and geophysical data is available, including detailed geological mapping, seismic reflection profiles, deep boreholes data, seismicity data, GPS measurements, and 


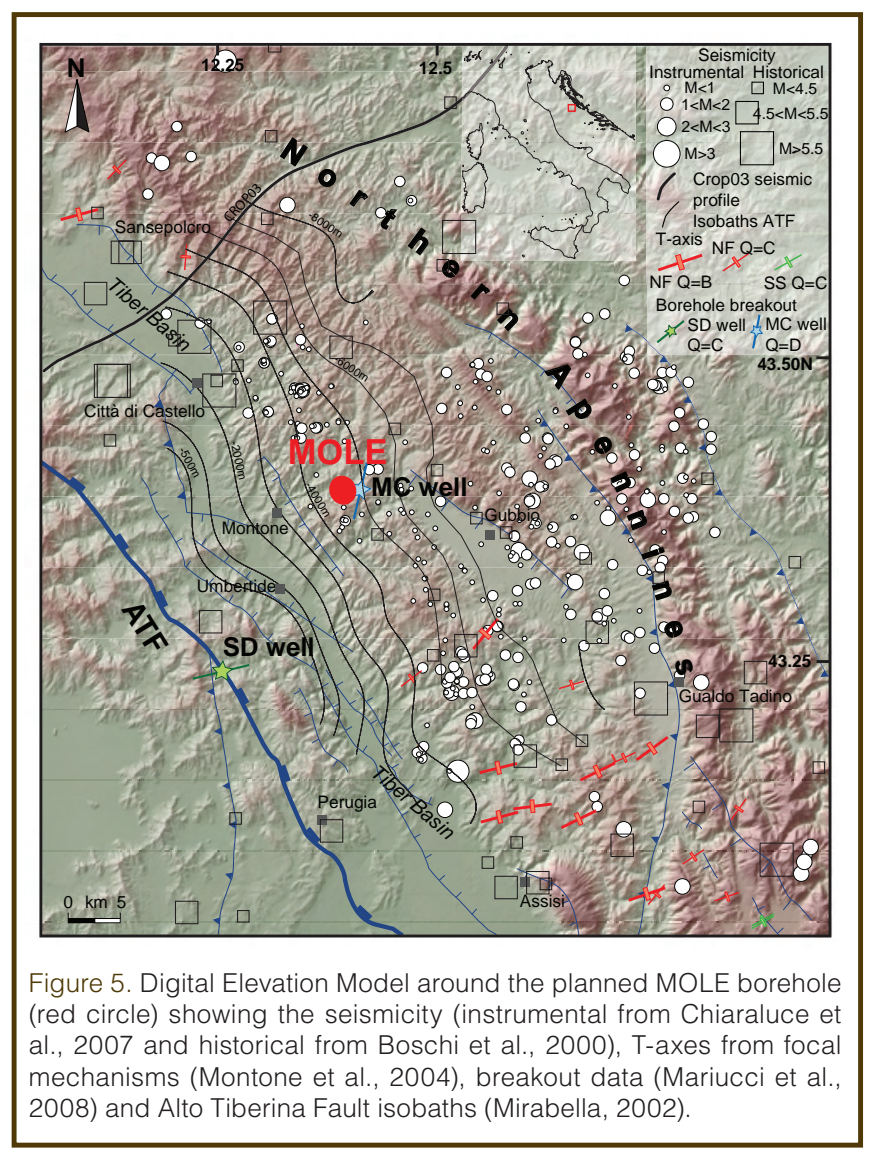

more. These data support the fact that the ATF is an active LANF. The workshop participants concluded that the potential ATF drilling site is ideal for setting up a unique laboratory to investigate the mechanics and the seismogenic potential of active LANFs. However, prior to drilling it will be necessary to improve hypocenter determination and collect site survey data in new seismic and geodetic campaigns, including high resolution seismic reflection data to better image and constrain depth of the target.

An interesting opportunity that emerged during the workshop was the re-opening of Monte Civitello well, which was closed many years ago by AGIP company through the injection of several plugs. The ATF was not identified during the drilling of Monte Civitello well probably because the drilling was stopped just above it. We are presently evaluating the possibility of re-opening Monte Civitello in order to install a deep array of seismometers and possibly to monitor geofluids at an expected maximum depth of nearly $2000 \mathrm{~m}$.

Another key conclusion from the workshop was to start drilling with a 2-km-deep pilot hole very close to the final MOLE borehole. This will allow for further detailed observations at depth to refine existing crustal structure models and to implement monitoring activities with particular attention to deep geo-fluids. Moreover, this will provide new data through borehole logging and sampling that will help to set up a permanent observatory at depth and improve planning for the deep hole.

\section{Summary}

One of the main conclusions of the workshop was that drilling through the Alto Tiberina Fault will provide information on crustal stress and fluid pressures. It will also allow us to do the following: (I) sample fault zone materials to measure their physical properties; (II) install down-hole seismometers, strainmeters, and fluid chemistry recorders to measure seismicity, strain rate, and transmigration of fluids; and (III) better understand the fault zone structure of a normal fault dipping at $\sim 15^{\circ}-20^{\circ}$, of which the seismogenic potential is unknown. Taken together, these studies will directly address many of the key questions related to the LANF paradox with particular regard to the understanding of the local stress field within the fault zone and the role of fluids in this process.

While the main goals of the MOLE project are to improve the understanding of the mechanical and physico-chemical behavior of LANFs, the impact of the project is certainly broader. The collected data and direct observations will provide a step toward more realistic models of earthquake nucleation and strain localization within fault zones. Laboratory experiments on rock friction with real and fresh fault zone materials can provide important constraints on fault friction and dynamic fault weakening processes. In general, MOLE will become a natural laboratory for monitoring and modeling the geophysical and geochemical processes controlling normal faulting in an active tectonic setting.

\section{Acknowledgements}

Many thanks to M.T. Mariucci and S. Pierdominici for the critical reading of this paper and for the preparation of some figures. Thanks are also due to A. Amato and L. Chiaraluce for corrections. We are grateful to ICDP and INGV for sponsoring the workshop that was officially patronized by Regione Umbria. We thank ENI S.p.A. and all workshop participants.

\section{References}

Amato, A., and Cocco, M., 2000. Special Issue: The Umbria-Marche, Central Italy, Seismic Sequence of 1997-1998. J. Seismol., 4: 5-598.

Anelli, L., Gorza, M., Pieri, M., and Riva, M., 1994. Subsurface well data in the Northern Apennines. Mem. Soc. Geol. It., 48: 461-471.

Axen, G.J., 1999. Low-angle normal fault earthquakes and triggering. Geophys. Res. Lett., 26: 3693-3696, doi:10.1029/ 1999 GL005405.

Axen, G.J., 2007. Research Focus: Significance of large-displacement, low-angle normal faults. Geology, 35(3): 287-288.

Boncio, P., Ponziani, F., Brozzetti, F., Barchi, M., Lavecchia, G., and Pialli, G., 1998. Seismicity and extensional tectonics in the Northern Umbria-Marche Apennines. Mem. Soc. Geol. It., 52: 539-555. 
Boschi, E., Guidoboni, E., Ferrari, G., Mariotti, D., Valensise, G., and Gasperini, P., 2000. Catalogue of Strong Italian Earthquakes. Annali di Geofisica, 43(4), 268 pp., with database on CD-ROM.

Byerlee,J.D., 1978. Friction of rocks. Pure Appl. Geophys., 116:615-629, doi:10.1007/BF00876528.

Chiaraluce, L., Chiarabba, C., Collettini, C., Piccinini, D., and Cocco, M., 2007. Architecture and mechanics of an active low angle normal fault: the Alto Tiberina fault (northern Apennines, Italy) case study. J. Geophys. Res., 112: B10310, doi:10.1029/2007JB005015.

Chiodini, G., Cardellini, C., Amato, A., Boschi, E., Caliro, S., Frondini, F., and Ventura, G., 2004. Carbon dioxide Earth degassing and seismogenesis in central and southern Italy. Geophys. Res. Lett., 31: L07615, doi:10.1029/ 2004GL019480.

Collettini, C., 2002. Hypothesis for the mechanics and seismic behaviour of low-angle normal faults: the example of the Altotiberina fault Northern Apennines. Ann. Geophys., 45(5): 683-698.

Collettini, C., and Barchi, M.R., 2002. A low angle normal fault in the Umbria region (Central Italy): a mechanical model for the related microseismicity. Tectonophysics, 359: 97-115.

Collettini, C., and Holdsworth, R.E., 2004. Fault zone weakening processes along low-angle normal faults: insights from the Zuccale Fault, Isle of Elba, Italy.J. Geol. Soc., 161: 1039-1051, doi:10.1144/0016-764903-179.

Collettini, C., and Sibson, R.H., 2001. Normal faults normal friction? Geology, 29(10): 927-930, doi:10.1130/0091-7613 (2001) 029<0927:NFNF $>2.0 . C O ; 2$.

D’Agostino, N., Mantenuto, S., D'Anastasio, E., Avallone, A., Barchi, M., Collettini, C., Radicioni, F., Stoppini, A., and Fastellini, G., 2008. Contemporary crustal extension in the UmbriaMarche Apennines from regional CGPS networks and comparison between geodetic and seismic deformation. Tectonophysics, in press, doi:10.1016/j.tecto.2008.09.033.

Deschamps, A., Courboulex, F., Gaffet, S., Lomax, A., Virieux, J., Amato, A., Azzara, A., Castello, B., Chiarabba, C., Cimini, G.B., Cocco, M., Di Bona, M., Marghereti, L., Mele, F., Selvaggi, G., Chiaraluce, L., Piccinini, D., and Ripepe M., 2000. Spatio-temporal distribution of seismic activity during the Umbria-Marche crisis, 1997. J. Seismol., Special Issue, 4:377-386, doi:10.1023/A:1026568419411.

Ekström, G., Morelli, A., Boschi. E., and Dziewonski, A.M., 1998. Moment tensor analysis of the central Italy earthquake sequence of September-October 1997. Geophys. Res. Lett., 25:1971-1974.

Floyd, J.S., Mutter, J.C., Goodliffe, A.M., and Taylor, B., 2001. Evidence for fault weakness and fluid flow within active lowangle normal fault. Nature, 411:779-783, doi:10.1038/35081040.

Haessler, H., Gaulon, R., Rivera, L., Console, R., Frogneux, M., Gasparini, G., Martel, L., Patau, G., Siciliano, M., and Cisternas, A., 1988. The Perugia (Italy) earthquake of 29 April 1984: a microearthquake survey. Bull. Seismol. Soc. Am., 78:1948-1964.

Hayman, N.W., Knott, J.R., Cowan, D.S., Nemser, E., and SarnaWojcicki, A.M., 2003. Quaternary low-angle slip on detachment faults in Death Valley, California. Geology, 31: 343-346.
Holdsworth, R.E., 2004. Weak faults-rotten cores. Science, 303:181-182, doi:10.1126/science.1092491.

Jackson, J.A., and White, N.J., 1989. Normal faulting in the upper continental crust: Observations from regions of active extension. J. Struct. Geol., 11:15-36, doi:10.1016/ 0191-8141(89)90033-3.

Mariucci, M.T., Montone, P., and Pierdominici, S., 2008. Active stress field in central Italy: a revision of deep well data in the Umbria region. Ann. Geophys., 51, 2/3, in press.

Mirabella, F., 2002. Seismogenesis of the Umbria- Marche region (Central Italy): Geometry and kinematics of the active faults and mechanical behaviour of the involved rocks. Ph.D. thesis, University of Perugia, Perugia, Italy, $121 \mathrm{pp}$.

Mirabella, F., Ciaccio, M.G., Barchi, M.R., and Merlini, S., 2004. The Gubbio normal fault (Central Italy): geometry, displacement distribution and tectonic evolution. J. Struct. Geol., 26:2233-2249, doi:10.1016/j.jsg.2004.06.009.

Montone, P., Mariucci, M.T., Pondrelli, S., and Amato, A., 2004. An improved stress map for Italy and surrounding regions (central Mediterranean). J. Geophys. Res., 109:B10410, doi:10.1029/2003JB002703.

Pialli, G., Barchi, M., and Minelli, G., 1998. Results of the CROP03 deep seismic reflection profile. Mem. Soc. Geol. It., 52, 654 pp.

Piccinini, D., Cattaneo, M., Chiarabba, C., Chiaraluce, L., De Martin, M., Di Bona, M., Moretti, M., Selvaggi, G., Augliera, P., Spallarossa, D., Ferretti, G., Michelini, A., Govoni, A., Di Bartolomeo, P., Romanelli, M., and Fabbri, J., 2003. A microseismicity study in a low seismicity area of Italy: the Città di Castello 2000-2001 experiment. Ann. Geophys., 46(6): 1315-1324.

Sibson, R.H., 1985. A note on fault reactivation. J. Struct. Geol., 7:751-754, doi:10.1016/0191-8141(85)90150-6.

Sorel, D., 2000. A Pleistocene and still-active detachment fault and the origin of the Corinth-Patras rift, Greece. Geology, 28:83-86, doi:10.1130/0091-7613(2000)28<83:APASDF>2.0.CO;2.

Wernicke, B., 1995. Low-angle normal faults and seismicity: A review. J. Geophys. Res., 100:20159-20174, doi:10.1029/95JB01911.

Zoback, M.D., 2007. Reservoir Geomechanics, Cambridge, UK (Cambridge University Press), 449 pp.

\section{Authors}

Massimo Cocco and Paola Montone, Istituto Nazionale di Geofisica e Vulcanologia (INGV), Via di Vigna Murata, 60500143, Rome, Italy, e-mail: cocco@ingvit.

Massimiliano R. Barchi, University of Perugia, Dipartimento di Scienze della Terra, Piazza dell'Università, 1, 06100 Perugia, Italy.

Georg Dresen, GeoForschungsZentrum Potsdam (GFZ), Telegrafenberg 14473, Potsdam, Germany.

Mark D. Zoback, Stanford University, Department of Geophysics, Mitchell Building 347, Stanford, Calif. , 943054606, U.S.A.

\section{Related Web Link}

http://mole.icdp-online.org 